\title{
Assessment of hot-melt coating methods for multiparticulate substrates: mortar-coating vs. pan-coating
}

\section{Jelisaveta Ignjatović ${ }^{1}$, Jelena Djuriš ${ }^{1}$, Mihal Djuriš ${ }^{2}$, Teodora Bočarski ${ }^{1}$, Vanja Vasilijević ${ }^{1}$, Ivana Aleksić ${ }^{1}$, Sandra-Cvijićc ${ }^{1 *}$}

${ }^{1}$ University of Belgrade - Faculty of Pharmacy, Department of Pharmaceutical Technology and Cosmetology, Vojvode Stepe 450, 11221 Belgrade, Serbia

${ }^{2}$ University of Belgrade - Institute of Chemistry, Technology and Metallurgy - National Institute of the Republic of Serbia, Department of Catalysis and Chemical Engineering, Njegoševa 12, 11000 Belgrade, Serbia

*Corresponding author: Sandra Cvijić, E-mail: gsandra@pharmacy.bg.ac.rs

\section{Abstract}

Hot-melt coating (HMC) is an alternative, solvent-free coating method generally used to modify substrate release rate and/or mask its unpleasant taste. The aim of this study was to assess two HMC methods (pan-coating and mortar-coating) by assaying functional properties of the coated material. The selected substrates included highly soluble sodium chloride (model substance) and caffeine (bitter drug), and the coating agent was glycerol distearate without/with the addition of liquid paraffin.

Experiments with sodium chloride revealed that pan-coating yielded particles of more regular shape, while mortar-coating yielded samples of more uniform coating layer. The flowability of the coated material depended on the particle size. Sustained sodium chloride release was achieved for all mortar-coated and some pan-coated samples. The analysis of the results indicated mortar-coating as a preferable HMC method for caffeine coating. The resulting caffeine yield in the coated samples was high $(99 \%)$, the material showed satisfactory mechanical properties and drug release from the coated particles was sustained. Overall, the obtained results suggest that both pan- and mortar-coating can be used to sustain the release of drugs with unpleasant taste, but mortar-coating can be considered as a more simple and practical method that can be potentially used in compounding pharmacies.

Keywords: hot-melt coating, pan-coating, mortar-coating, multiparticulates, functional properties

DOI: https://doi.org/10.5937/arhfarm71-30266 


\section{Introduction}

Coating of a substrate (drug or solid dosage form) is a versatile technique used in the formulation of pharmaceutical dosage forms since it can provide modified drug release and improve substrate palatability, as well as physical and chemical drug/dosage form stability (1). Improved palatability of a dosage form (e.g., taste, aftertaste, texture) is especially important characteristic for multiparticulate or orodispersible dosage forms, since they are often administered to pediatric, geriatric and patients with reduced swallowing ability. Unpleasant taste of a number of drug substances is considered as one of the major issues in the formulation of acceptable oral dosage forms, and therefore pharmaceutical industry has made great efforts to develop appropriate methods for drugs taste masking $(2,3)$. Some pros and cons of these methods are still to be determined, including their applicability for drug taste masking in ex tempore compounding practice, which has been rather neglected in comparison to pharmaceutical development under industrial settings.

Substrate coating is one of the approaches for drug taste masking (4), and this approach includes several methods such as sugar coating, film coating, compression coating, hot-melt coating (HMC), supercritical fluid-based coating, or spray-drying coating (5-7). Film coating with aqueous- or organic-based polymeric solution or dispersion is the most frequently used coating technique in the pharmaceutical industry (1). However, this method is associated with numerous disadvantages such as potential toxicity, flammability and high cost of organic solvents, or microbiological contamination and stability issues due to the residual moisture from aqueous polymeric solutions/dispersions $(8,9)$. In order to overcome these limitations, novel solvent-free methods, such as HMC, are being developed. The application of HMC for substrate taste masking has already been reported in literature (10-13).

HMC is an alternative coating method, where a substrate is coated with a molten lipid that solidifies upon cooling, forming a compact coating layer. This process possesses several advantages: (i) it is environmentally friendly due to the exclusion of the usage of organic solvents; (ii) coating time and overall production costs are reduced; (iii) there is no risk of bacteriological contamination and hydrolysis of a drug; (iv) lipid excipients are economically affordable, and most of them are classified as Generally Recognized As Safe (GRAS) $(9,10,14)$. Despite these benefits, HMC is associated with some limitations such as: (i) the inability to coat thermolabile drugs; (ii) polymorphic transitions of certain lipid excipients; (iii) potential stickiness and agglomeration of HMC coated particles (8, $10,15)$. The most commonly used coating excipients for HMC are biodegradable lipids such as partial glycerides, polyoxylglycerides, fatty acids, vegetable oils and waxes (15). These excipients are generally applied as a single or multi-component coating, although they can also be mixed with other types of excipients, such as polymers and surfactants (16-18). In addition, it may be hypothesized that the addition of a liquid lipid component 
(e.g., liquid paraffin) to the molten lipid coat might improve the uniformity of coating (i.e., decreased viscosity of the melted lipid might improve its spreading capacity).

In the industrial setting, HMC is usually performed using a fluid bed coater or a pan coater (9). Both types of equipment, however, require special design or additional modifications to convey the molten excipient and maintain its temperature during the coating process $(9,10)$. On the other hand, HMC can also be performed by direct blending of a suitable molten lipid and a substrate in a mortar, which is a simpler method that can potentially be used for substrate coating in compounding pharmacies.

HMC of multiparticulate substrates (powders, granules, pellets) is an additional challenge in comparison to HMC of single unit dosage forms due to agglomeration of the coated particles. In addition, coated multiparticulates should possess adequate functional characteristics such as particle shape and morphology, particle size distribution, flowability and substrate release rate from the coated material.

The aim of this study was to assess the benefits and limitations of two different HMC methods for multiparticulate substrate coating (mortar-coating vs. pan-coating) using glycerol distearate as a lipid excipient, and analyse the influence of the HMC method on the functional characteristics of the coated material i.e., particle size and shape, flowability, and sustained drug/substrate release as an indicator of the substrate taste masking efficacy. Two highly soluble substrates were used for this purpose: sodium chloride as a model substrate, and caffeine as a drug with bitter taste.

\section{Experimental part}

\section{Materials}

Sodium chloride (Sigma-Aldrich, USA) and caffeine anhydrous (Sigma-Aldrich Chemie $\mathrm{GmbH}$, Germany) were used as model substrates. Glycerol distearate (Precirol ${ }^{\circledR}$ ATO5, Gattefossé SAS, France) was used as a lipid coating agent, and red dye powder as a colouring agent. Liquid paraffin (Fagron, Netherlands), as a recognized viscosity modifier $(19,20)$, was used to adjust the molten coat viscosity.

\section{HMC of the substrates}

Two different methods were applied for the substrate coating with glycerol distearate as a coating agent. In the first step, sodium chloride was coated in the pan coater and in a mortar. In the next step, the selected HMC procedure was used to coat caffeine. Seven samples were prepared in total, six with sodium chloride (F1-F6), and one with caffeine (F7). Each sample batch size weighted $240 \mathrm{~g}$. the composition of the samples and the selected HMC method are presented in Table I. 
Table I Composition of the samples and the selected HMC method

Tabela I Sastav uzoraka i odabrani postupak oblaganja topljenjem

\begin{tabular}{|c|l|l|}
\hline Sample & Composition & HMC method \\
\hline F1 & $\begin{array}{l}\text { sodium chloride: glycerol distearate: } \\
\text { liquid paraffin }=10: 1: 1\end{array}$ & pan coater \\
\hline F2 & $\begin{array}{l}\text { sodium chloride: glycerol distearate: } \\
\text { liquid paraffin }=10: 2: 1\end{array}$ & pan coater \\
\hline F3 & sodium chloride: glycerol distearate $=10: 1$ & pan coater \\
\hline F4 & sodium chloride: glycerol distearate $=10: 2$ & pan coater \\
\hline F5 & sodium chloride: glycerol distearate $=10: 2$ & $\begin{array}{l}\text { mortar } \\
\text { (lipid added to substrate) }\end{array}$ \\
\hline F6 & sodium chloride: glycerol distearate $=10: 2$ & $\begin{array}{l}\text { mortar } \\
\text { (substrate added to lipid) }\end{array}$ \\
\hline F7 & caffeine: glycerol distearate $=10: 2$ & $\begin{array}{l}\text { mortar (substrate added to } \\
\text { lipid) }\end{array}$ \\
\hline
\end{tabular}

\section{HMC in the pan coater}

HMC of the substrate in the pan coater (Erweka AR 400, pan type UG, Erweka $\mathrm{GmbH}$, Germany) was performed according to the method described by Sudke and Sakarakar (9). In brief, lipid excipient was molten and kept on a magnetic stirrer (IKA ${ }^{\circledR}$ Werke $\mathrm{GmbH}$, Germany) above its melting point, at $100{ }^{\circ} \mathrm{C}$ (melting point of glycerol distearate is $50-70{ }^{\circ} \mathrm{C}(21)$ ). Molten lipid was then added in a dropwise manner to sodium chloride during continuous stirring $(25 \mathrm{rpm})$ in the rotating pan coater. Stirring was continued for another $10 \mathrm{~min}$, and finally the coated material was left to solidify (under ambient conditions, in a thin layer) for 24 hours.

\section{HMC in a mortar}

HMC in a mortar was performed by heating the substrate and the coating agent in two separate mortars, kept on the magnetic stirrers (IKA ${ }^{\circledR}$ - Werke GmbH, Germany) at $100{ }^{\circ} \mathrm{C}$, followed by their manual mixing (cc. $90 \mathrm{rpm}$ ) i.e., coating step using two different procedures. For the first procedure, the molten lipid was slowly added to the preheated substrate $\left(100{ }^{\circ} \mathrm{C}\right)$ under continuous stirring and stirring was continued for another 10 min (sample F5). For the second procedure, the preheated substrate $\left(100{ }^{\circ} \mathrm{C}\right)$ was slowly added to the molten lipid under continuous stirring which continued for another $10 \mathrm{~min}$ 
(samples F6 and F7). The melting point of sodium chloride is $804{ }^{\circ} \mathrm{C} \mathrm{(22),} \mathrm{and} \mathrm{caffeine}$ 234-239 ${ }^{\circ} \mathrm{C}(21)$, indicating adequate thermal stability of the selected substrates under the applied HMC conditions.

\section{Characterization of the coated material}

The coated samples were analysed in terms of yield, particle size distribution, image analysis (particle size and shape), flowability, substrate content and release rate from the coated samples. Due to the differences in particles size, samples F3-F7 were sieved through $800 \mu \mathrm{m}$ mesh sieve and divided into coarse $(>800 \mu \mathrm{m}$ particles $)$ and fine fraction $(<800 \mu \mathrm{m}$ particles). Coarse fractions were marked by index $c(\mathrm{~F} 3 c-\mathrm{F} 7 c)$, and fine fractions by index $f(\mathrm{~F} 3 f-\mathrm{F} 7 f)$. Consequent analyses of particle size and shape, flow properties and substrate content and release rate were performed on F3-F7 coarse and fine fractions.

\section{Yield determination}

The yield for each sample was calculated as the relative ratio of the coated sample mass to the total mass of ingredients (expressed in percentage).

\section{Particle size distribution}

Particle size distribution of the coated samples was determined by the sieve analysis. Samples ( $25 \mathrm{~g}$ ) were weighed and sieved for $10 \mathrm{~min}$ using the vibratory sieve shaker (Erweka AR 400, Erweka GmbH, Germany) consisting of the following standard sieves (Retsch GmbH, Germany): 63, 125, 180, 250, 355, 500 and $800 \mu \mathrm{m}$. The fractions were collected, weighted individually, and expressed as a percentage of the total sample mass.

\section{Particle size and shape}

Size and shape (sphericity) of the particles were examined based on the analysis of the scanned images of the selected samples. Sample particles in sufficient quantity were evenly placed in the Hp Scanjet 300 scanner (Hewlett-Packard, USA). A contrasting black background, 4800 dpi resolution, and scan time of 45-60 min per sample were used for the scanning process. The obtained images were processed in the ImageJ software (23), and the following parameters were calculated to characterize size and shape of the particles: surface diameter (diameter of a sphere that has the same surface as a particle) and shape (circularity) factor. Shape (circularity) factor was calculated for the predominant particle size fraction of the selected samples. Circularity can be defined as the ratio of the surface area of a sphere to the surface area of a particle when their volumes are equal. The shape (circularity) factor value lies in the range between 0 and 1 , meaning that the particle is an ideal sphere when the shape factor equals 1. 


\section{Flowability}

The flowability of the coated samples, in comparison to the uncoated substrates, was determined by either direct (samples F2-F7) or indirect method (sample F1).

Direct method referred to the determination of the sample flow through an orifice. The time needed for $30 \mathrm{~g}$ sample to flow through $12 \mathrm{~mm}$ orifice of the flowmeter (Erweka GDT, Erweka GmbH, Germany) was recorded, and each sample was analysed in triplicate.

The indirect method to assess the samples flowability was based on calculation of the Hausner's ratio (HR) (equation 1) and the Compressibility (Carr's) index (CI) (equation 2).

$$
\begin{aligned}
& \mathrm{HR}=\frac{\text { tapped density }}{\text { bulk density }} \\
& \mathrm{CI}(\%)=\frac{\text { (tapped density - bulk density) }}{\text { tapped density }} \times 100
\end{aligned}
$$

Bulk density was calculated from the sample mass $(10 \mathrm{~g})$ and the corresponding volume using a $25 \mathrm{ml}$ graduated cylinder. Tapped density was calculated from the sample volume after 1250 taps on the volumeter StaV 2003 (J. Engelsmann AG, Germany). The flowability was expressed in descriptive terms, according to the European Pharmacopoeia $10^{\text {th }}$ ed. (Ph. Eur. 10.0), based on HR and CI values (21).

\section{Substrate content in the coated samples}

Each sample was accurately weighed $(0.1000 \pm 0.0005 \mathrm{~g})$, placed in a $50 \mathrm{ml}$ volumetric flask, and melted on a magnetic stirrer $\left(100^{\circ} \mathrm{C}\right)$ for $3 \mathrm{~min}$. Purified water, preheated to $80{ }^{\circ} \mathrm{C}$, was added to the flasks and the samples were sonicated for $5 \mathrm{~min}$ in ultrasonic bath (Sonorex RK 102H, Bandelin GmbH, Germany), at $45^{\circ} \mathrm{C}$. The sonicated samples were filtered $(0.45 \mu \mathrm{m}$ mixed cellulose esters membrane filters, Merck Millipore, USA), and the substrate concentration was quantitatively assayed using a suitable method: conductometry (SensION ${ }^{\mathrm{TM}}$, Hach Lange GmbH, USA) for sodium chloride, and UV spectrophotometry (Evolution 300 UV-VIS spectrophotometer, Thermo Fisher Scientific, USA) at $273 \mathrm{~nm}$ wavelength for caffeine. The content of the substrates was expressed as percent of the coated sample weight.

\section{Substrate release rate}

The accurately weighed $(1.000 \pm 0.005 \mathrm{~g})$ samples were transferred to the beakers filled with $50 \mathrm{ml}$ medium (purified water), and the beakers were placed on a shaker (KS 260 Basic, IKA, Germany), rotating at a speed of $150 \mathrm{rpm}$. At the predefined time intervals, $3 \mathrm{ml}$ aliquots were withdrawn from the beakers, filtered $(0.45 \mu \mathrm{m}$ mixed cellulose esters membrane filters, Merck Millipore, USA) and analysed by the methods described in 2.3.5. The volume of withdrawn medium was accounted for in the calculation 
of the dissolved substrate. Namely, due to the high solubility of sodium chloride and caffeine $(24,25)$, sink conditions were maintained throughout the test, without the need to replace the withdrawn medium. Substrate release profiles were compared by calculating the similarity factor, $f_{2}(26)$, where $f_{2}$ values higher than 50 indicate that two release profiles can be considered similar.

\section{Results and discussion}

\section{Characterization of the coated sodium chloride samples}

The determined yield values for the tested samples ranged between $95.76 \%$ (F5) and $98.45 \%$ (F6), indicating good HMC process efficiency.

Sieve analysis was performed for all the coated samples, except for sample F1. Namely, F1 was rather sticky, making it impossible for the particles to pass through the sieve. The obtained results (Figure 1) showed that the majority of uncoated sodium chloride particles sized between 125 and $355 \mu \mathrm{m}$, while the coated particles were mostly distributed within the size range from 355 to $800 \mu \mathrm{m}$, except for sample F4, where a large fraction of particles $>800 \mu \mathrm{m}$ was observed. As expected, HMC increased particle size due to the presence of coat, but relatively large coated samples size also indicated particle agglomeration, which will be analysed further. Unimodal particle size distribution was observed for uncoated sodium chloride particles, as well as for samples F2 and F3, while samples F4, F5 and F6 showed bimodal distribution with two dominant fractions i.e., $355-500 \mu \mathrm{m}$ and $>800 \mu \mathrm{m}$.

In order to provide more detailed data on the particle size and shape, we have analysed scanned images of uncoated sodium chloride and the selected coated samples. The selected samples included F4 and F6 (samples of the same composition, prepared by different HMC method) and F2 (similar composition as F4 and F6, but with the addition of liquid paraffin). The results are presented in Figures 2-4.

As observed in Figure 2, the particles from samples F4 and F6 formed agglomerates during the coating process, with visible differences in the agglomerates size. The presence of agglomerates was also visually observed for samples F3 and F5. Therefore, samples F3-F6 were sieved through $800 \mu \mathrm{m}$ mesh sieve, two fractions $(f$ and $c$ ) were collected for each sample, and further characterized separately. 


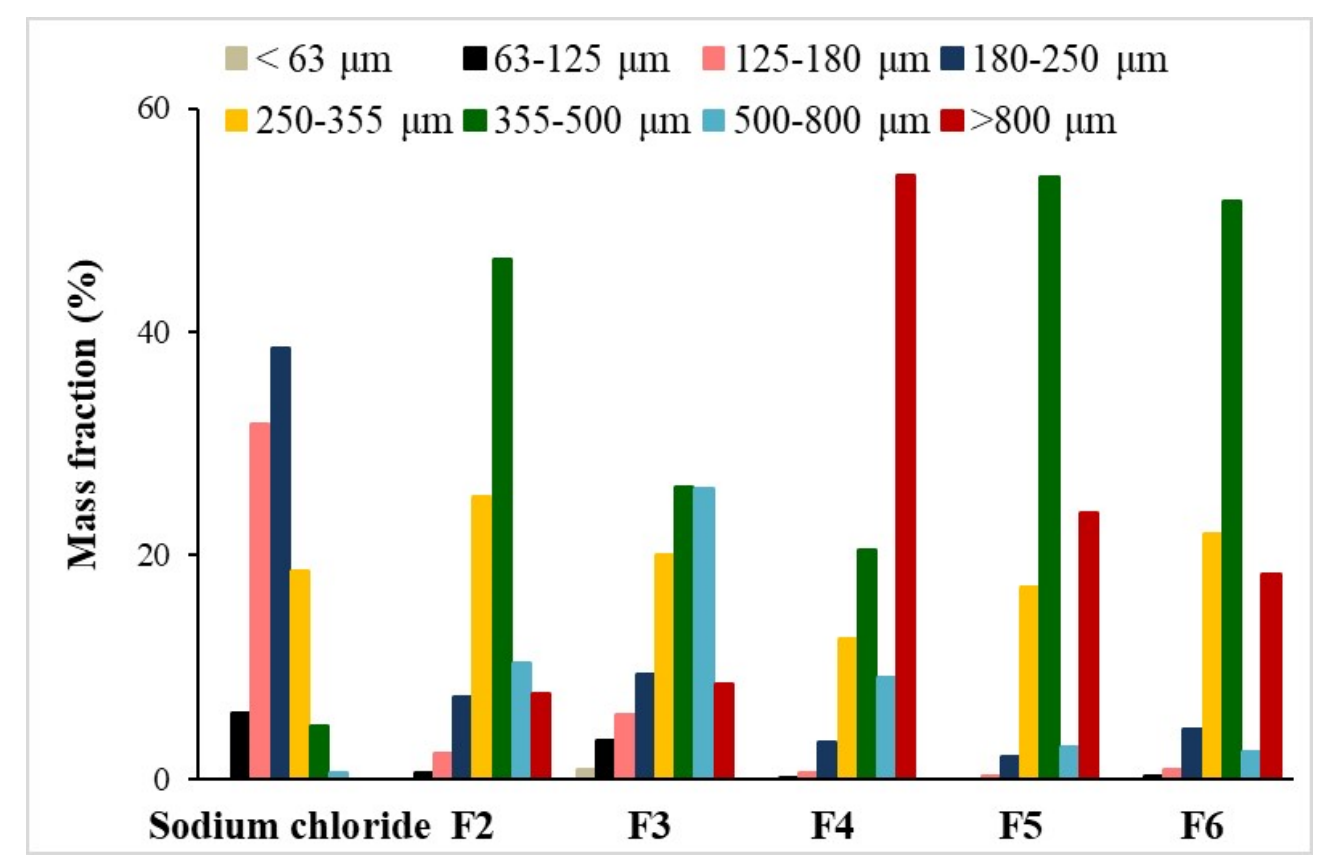

Figure 1. Particle size distribution of uncoated sodium chloride and coated samples, determined by sieve analysis

Slika 1. Raspodela veličine čestica neobloženog natrijum-hlorida i obloženih uzoraka, određena sitanom analizom

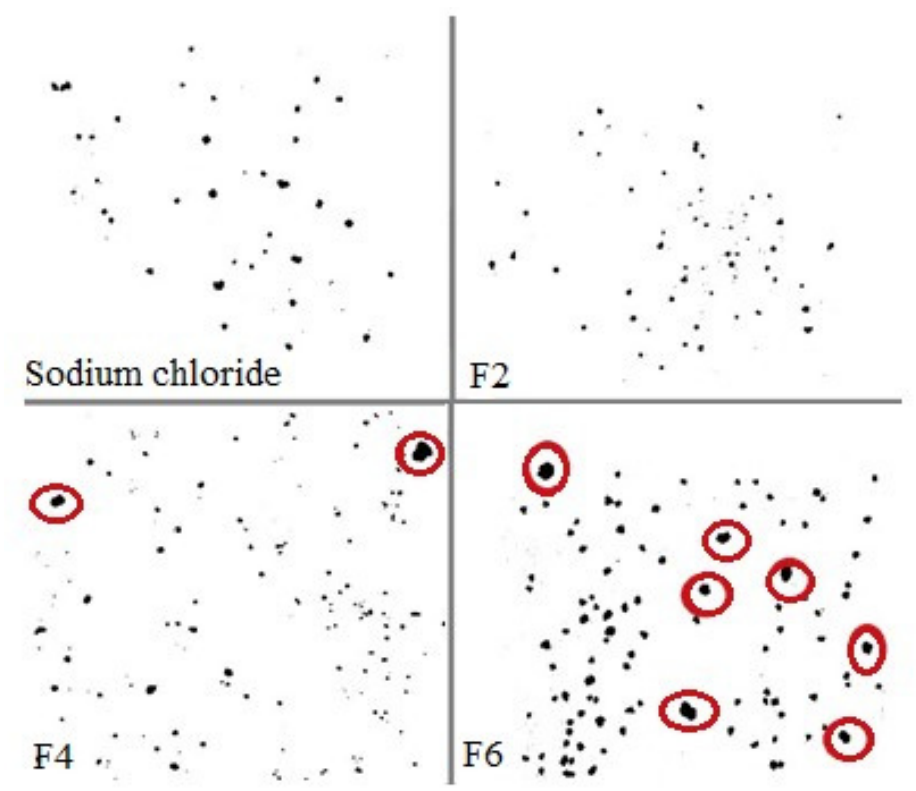

Figure 2. Scanned images of uncoated sodium chloride and samples F2, F4 and F6; examples of the agglomerates are framed in red

Slika 2. Skenirane slike čestica neobloženog natrijum-hlorida i uzoraka F2, F4 i F6; primeri aglomerata su uokvireni crveno 
The presented particle size distributions data (Figure 3) indicate that the particles of the mortar-coated sample (F6) are generally larger than the particles of the pan-coated samples (F2 and F4). On the other hand, the circularity factor (Figure 3) is higher for the pan-coated particles $(0.82,0.80$ and 0.75 for $\mathrm{F} 2, \mathrm{~F} 4 f$ and $\mathrm{F} 4 c$, respectively) in comparison to mortar-coated particles ( 0.74 and 0.69 for $\mathrm{F} 6 f$ and F $6 c$, respectively). In addition, pancoated particles (e.g., F2 and F4f) have higher circularity than uncoated sodium chloride particles, indicating that pan-coating can improve substrate particles shape. Figure 2 also demonstrates smaller circularity of $\mathrm{F} 6 f$ and $\mathrm{F} 6 c$ in comparison to uncoated sodium chloride and pan-coated $\mathrm{F} 2$, as a result of particle agglomeration, a phenomenon which may likely occur during HMC in a mortar since the mixture is stirred manually. The circularity factor for $\mathrm{F} 4 c$ indicates that particle agglomeration also happened during the pan-coating process, but to a lesser extent than in a mortar. Size and shape of the agglomerated coated particles (fine and coarse fractions) are also illustrated on Figure 4. Although pan-coating resulted in particles with more regular shape (represented by higher circularity factor of F4 in comparison to F6), Figure 4 reveals that coating of this sample was not uniform, as observed by the difference in colour between $\mathrm{F} 4 f$ and $\mathrm{F} 4 c$. On the other hand, both mortar-coated fractions (F6 $f$ and F $6 c$ ) showed relatively uniform coating layer.

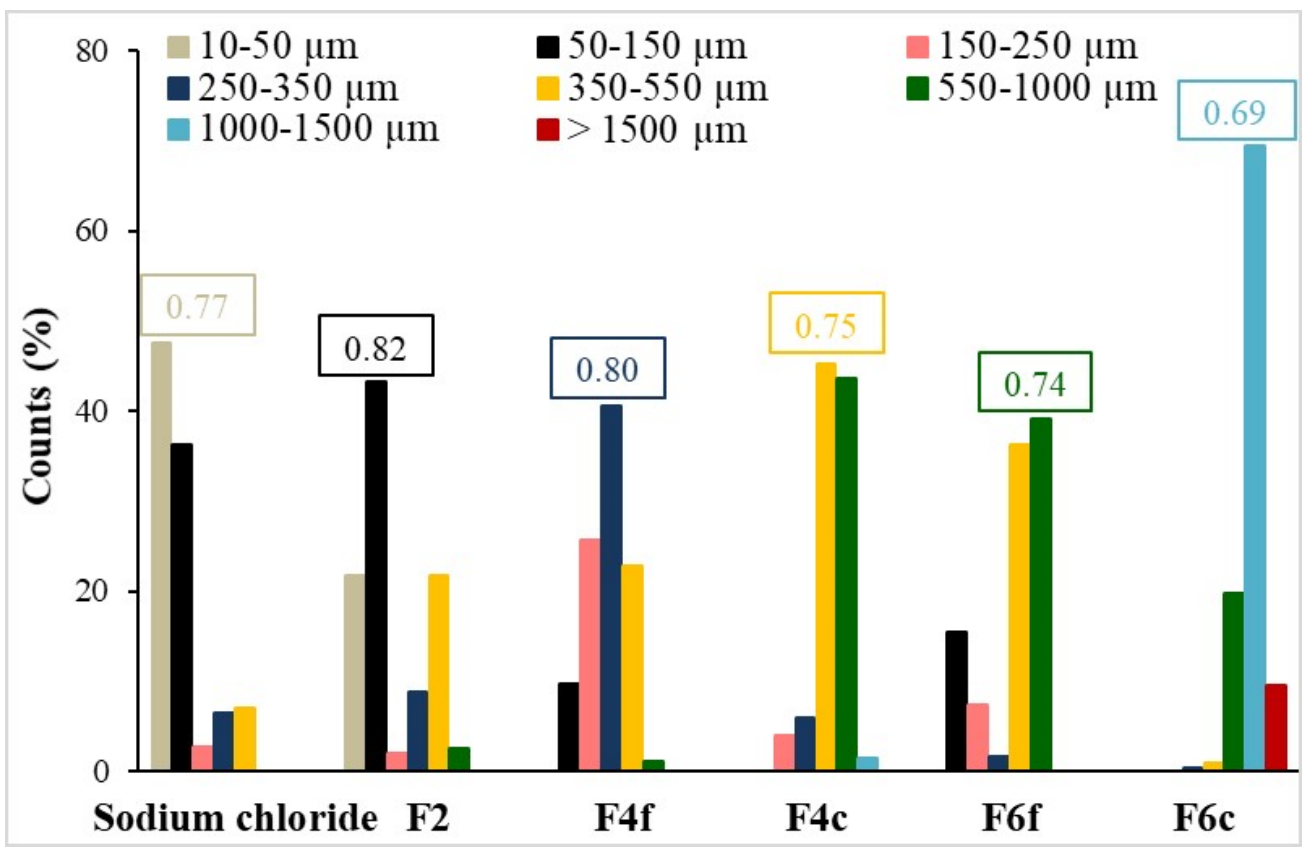

Figure 3. Particle size distribution and circularity factor (framed values) for the tested samples, determined by image analysis; coarse fractions are marked by index $c$ (F4c, F6c), and fine fractions by index $f(\mathrm{~F} 4 f, \mathrm{~F} 6 f)$

Slika 3. Raspodela veličine i cirkularnost (uokvireni brojevi) čestica ispitivanih uzoraka, određeni na osnovu analize slike; krupne frakcije su označene indeksom $c(\mathrm{~F} 4 c, \mathrm{~F} 6 c)$, a sitne frakcije indeksom $f(\mathrm{~F} 4 f, \mathrm{~F} 6 f)$ 

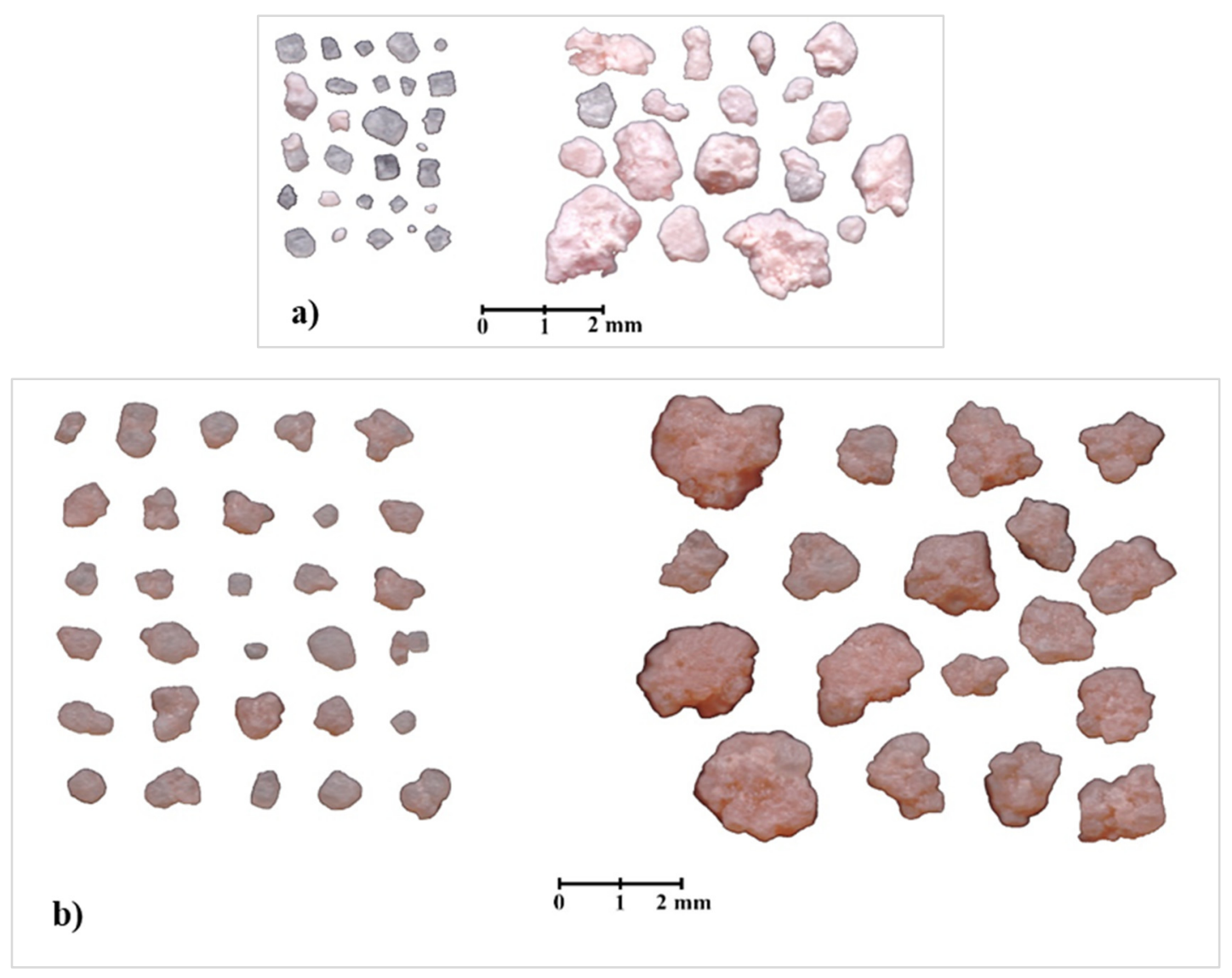

Figure 4. Scanned images of F4 (a) and F6 (b) samples: fine fractions (left) and coarse fractions (right)

Slika 4. Skenirane slike uzoraka F4 (a) i F6 (b): sitne frakcije (levo) i krupne frakcije (desno)

The flowability results, determined by the direct method (Figure 5), revealed that all HMC samples tend to have decreased flowability in comparison to the uncoated sodium chloride. This observation suggests that HMC process alters the material flowability in general; however, flow properties also depend on the coating method and the coating composition. Among the coated samples, F2 showed the best flowability, followed by samples F4 and F3. Better flowability of samples F2 and F4 e.g., in comparison to sample F6 can be attributed to the higher sphericity of these particles (Figure 3). On the other hand, F5c and F6c exhibited the lowest flowability. Such results suggest that an increase in particle size (due to HMC or concomitant agglomeration) decreases the flowability of a mortar-coated samples. This observation is only partially true, because the flowability of the coated particles is influenced not only by their size and shape, but also by the changes in the texture and adhesiveness of the particle surface, which depends on the substrate characteristics, coating composition and coating method. 


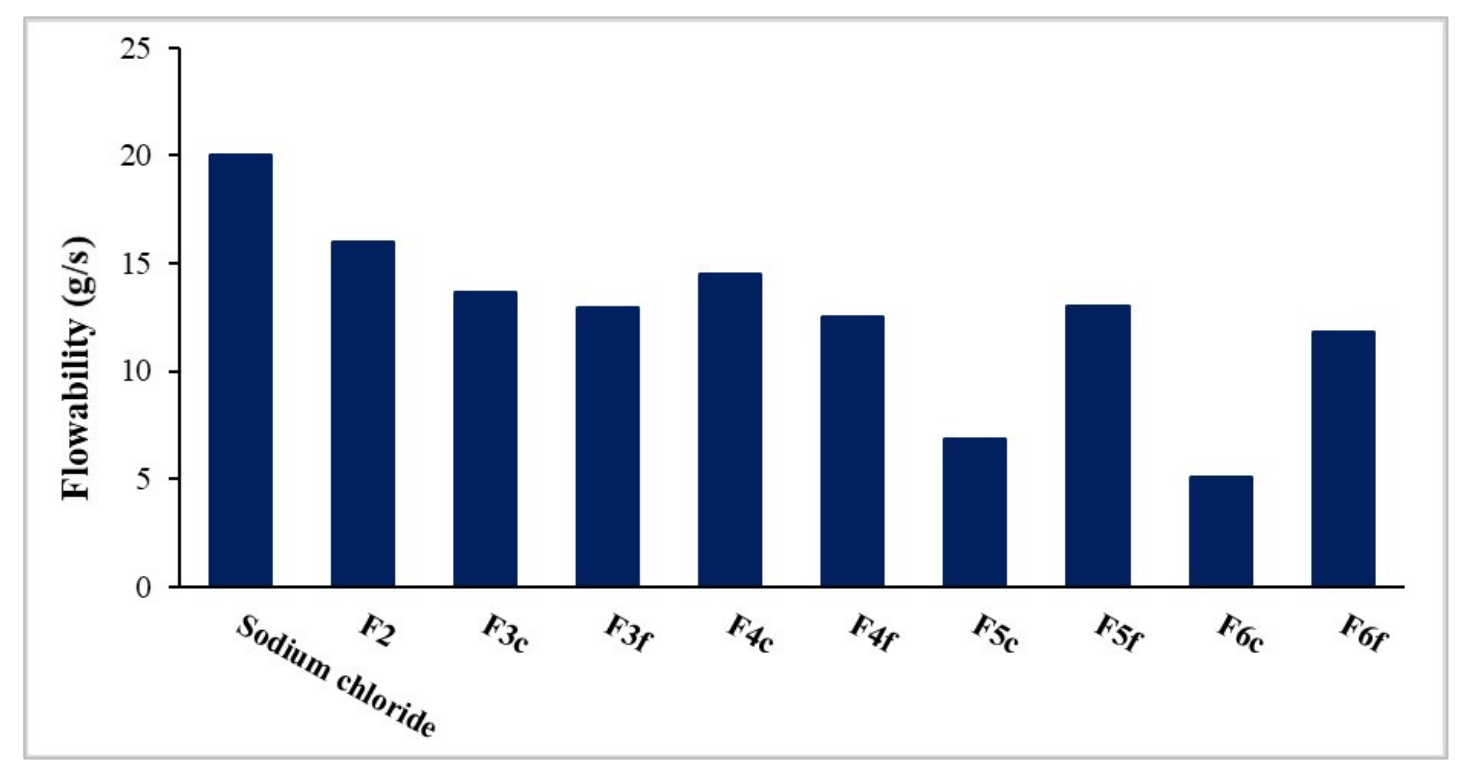

Figure 5. Flowability of uncoated sodium-chloride and samples F2-F6, determined by the direct method; coarse fractions are marked by index c (F3c-F6c), and fine fractions by index $f$ (F3f-F6f)

Slika 5. Protočnost neobloženih čestica natrijum-hlorida i uzoraka F2-F6, određena direktnom metodom; krupne frakcije su označene indeksom c (F3c-F6c), a sitne frakcije indeksom $\mathbf{f}$ (F3f-F6f)

As mentioned before, the flowability of sample F1 was determined by the indirect method. This sample could not be tested using the direct method, because it was too sticky (due to relatively large portion of liquid paraffin) to pass through the orifice of the flowmeter. According to the obtained results (Table II), flowability of F1 can be classified as "very, very poor", signifying that the applied coating notably decreased the material flow properties.

Table II Flowability of sample F1 in comparison to uncoated sodium-chloride, determined by the indirect method

Tabela II Protočnost uzorka F1 u odnosu na čestice neobloženog natrijum-hlorida, određena indirektnom metodom

\begin{tabular}{|c|c|c|c|c|c|c|}
\hline Sample & Mass (g) & $\begin{array}{c}\text { Bulk } \\
\text { density } \\
\text { (g/ml) }\end{array}$ & $\begin{array}{c}\text { Tapped } \\
\text { density } \\
\text { (g/ml) }\end{array}$ & CI (\%) & HR & Flowability* \\
\hline $\begin{array}{c}\text { sodium } \\
\text { chloride }\end{array}$ & 10.00 & 1.12 & 1.25 & 11.11 & 1.12 & good \\
\hline F1 & 10.00 & 0.48 & 0.77 & 38.10 & 1.62 & very, very poor \\
\hline
\end{tabular}

*Terminology according to the Ph. Eur. 10 (21) 
Sodium chloride content in the investigated samples ranged between $55.59 \%$ and $79.43 \%$, and these values were used to calculate the substrate release rate (in percentage) from the samples. The obtained sodium chloride release profiles are depicted in Figure 6.

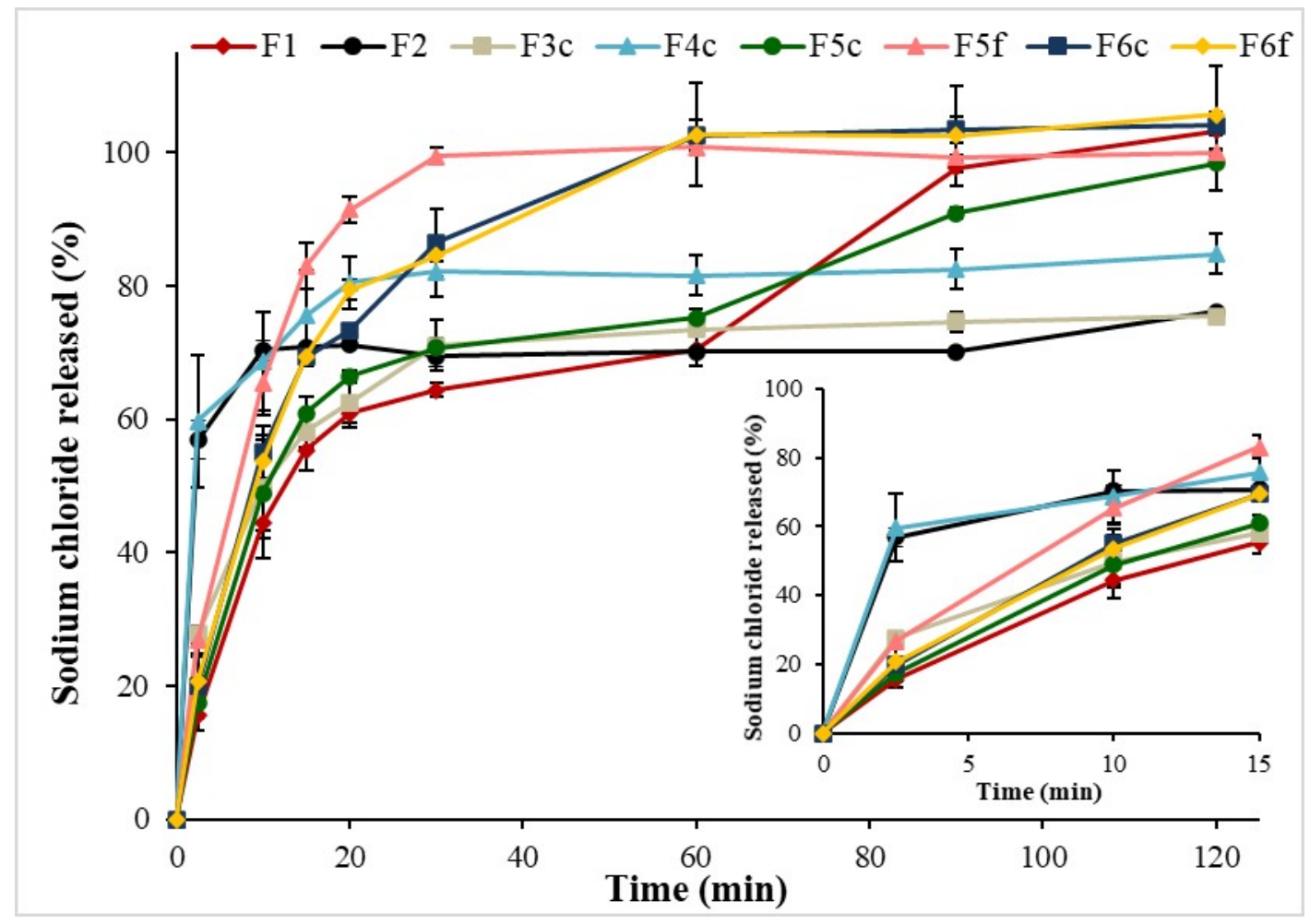

Figure 6. Sodium chloride dissolution profiles from the selected samples; coarse fractions are marked by index $c($ F3c-F6c), and fine fractions by index $f(F 5 f$, F6 f). The inset shows the magnified initial phase (up to $15 \mathrm{~min}$ ) of the dissolution profiles

Slika 6. Profili brzine rastvaranja natrijum-hlorida iz odabranih uzoraka; krupne frakcije su označene indeksom $c(\mathrm{~F} 3 c-\mathrm{F} 6 c)$, a sitne frakcije indeksom $f(\mathrm{F5} f$, F6f). Umetnuta slika predstavlja uveličanu inicijalnu fazu (do $15 \mathrm{~min}$ ) u profilima brzine rastvaranja supstrata

Based on the results of substrate content, it is possible to evaluate the efficiency of the applied HMC method since lower substrate content indicates higher proportion of lipid coat, which means higher HMC efficiency. In addition, based on the results of substrate release rate, it is also possible to indirectly evaluate the efficiency of the applied HMC methods, where slower substrate release rate generally indicates higher HMC efficiency. This means that lower substrate content (higher proportion of lipid coat) may be related to a slower or less complete substrate release rate and vice versa, as observed in our study (e.g., relatively high substrate content $(79.15 \%) /$ low proportion of lipid in sample F2 resulted in the initial burst drug release). Moreover, larger (coarse) particles 
are generally expected to exhibit slower substrate release rate; therefore, only coarse fractions of some samples were analysed. As observed in Figure 6, a substantial amount of substrate was initially released from the pan-coated samples F2 and F4c (almost 60\% in $2.5 \mathrm{~min}$ ) suggesting that the coating efficacy was not satisfactory for these two samples. This finding is in agreement with the image analysis data i.e., Figure 4 also indicates nonuniform coating of sample F4. Therefore, poorly coated particles of F4c sample released the substrate relatively fast, while the remaining particles (with thicker lipid coat) suppressed further release of sodium chloride as illustrated in the incomplete dissolution profile (Figure 6). Incomplete dissolution was also observed in the case of F2 sample. In this case, the sample showed a tendency to float, and due to poor wetting of such particles, drug release after initial burst was retained (Figure 6). Pan-coated samples F1 and F3c exhibited sustained sodium chloride release due to formation of large agglomerates (caused by stickiness) in sample F1 or conspicuous particles floating and consequent poor wetting of sample F3c. The mortar-coated samples also exhibited rather slow substrate release (about 20\% dissolved sodium chloride in $2.5 \mathrm{~min}$ ), with no burst effect. These results indicate that the applied HMC method in a mortar can be effective in suppressing the unpleasant taste of drugs. In addition, the substrate release rate from the sample F6 fractions $(\mathrm{F} 6 c$ and $\mathrm{F} 6 f)$ were similar $\left(\mathrm{f}_{2}=80.12\right)$, while a pronounced difference $\left(\mathrm{f}_{2}=\right.$ 36.77) was seen between F5 fractions (F5c and F5f). This observation suggested that the addition of a substrate to the molten lipid might be a more suitable HMC method than vice versa.

\section{Selection of the coating method for further studies}

Sodium chloride was selected as an initial model substrate with high solubility (357 $\mathrm{mg} / \mathrm{mL}$ on $\left.25^{\circ} \mathrm{C}\right)(24)$ to evaluate whether the tested HMC methods can produce coated material with appropriate functional characteristics and sustained substrate release. The influence of the amount of the coating excipient (in relation to the substrate amount) and the composition of the coating layer were also assessed.

The highest yield of the coated sodium chloride particles was achieved with the mortar-coating method, where the substrate was added to the molten lipid (sample F6). Also, mortar-coating method resulted in more uniform coating layer than the pan-coating method, as shown by the image analysis (Figure 4). On the other hand, pan-coated samples (except F1) showed the best flow properties, although fine fractions of mortarcoated samples (F5f and F6f) also exhibited comparable flowability. These findings indicate that adequate sample flowability can be achieved using both methods, depending on the lipid percentage, coating composition, the resulting particle size etc. As for the substrate release rate, all mortar-coated samples (F5c, F5f, F6c and F6f) exhibited rather slow sodium chloride release, indicating good process coating efficacy, while some pancoated samples (F2 and F4c) exhibited fast initial substrate release. In addition, no observable difference in the substrate release rate between coarse and fine fractions of 
sample F6 indicated that the material coated in a mortar by adding a substrate to the molten lipid may possess more uniform dissolution characteristics.

Based on the overall results, mortar-coating (addition of substrate to lipid) was selected for the model drug (caffeine) coating.

\section{Characterization of the coated caffeine sample}

The calculated yield for HMC caffeine sample (F7) was 99\%, proving the high efficiency of the selected HMC method.

Particle size distribution data are presented on Figure 7. Uncoated caffeine particle size distribution was rather wide in comparison to the mortar-coated sample F7. As in the case of sodium chloride, substrate coating resulted in substantial particle size increase. Sample F7 mostly consisted of particles larger than $800 \mu \mathrm{m}$, while one third of particles lied in the size range of 355-800 $\mu \mathrm{m}$ (Figure 7).

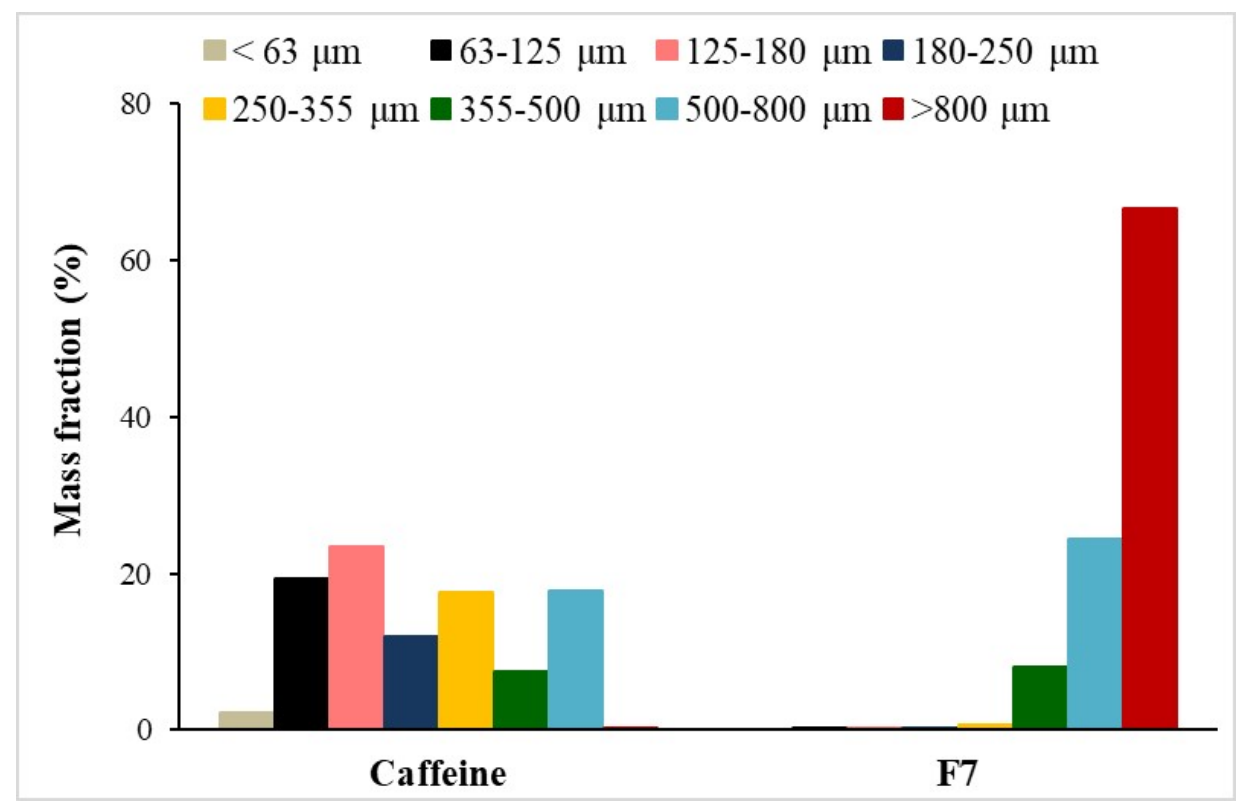

Figure 7. Particle size distribution of uncoated caffeine and sample F7, determined by sieve analysis

Slika 7. Raspodela veličine čestica neobloženog kofeina i uzorka F7, određena sitanom analizom

As in the case of sodium chloride samples, F7 was divided into fine and coarse fraction by sieving through the $800 \mu \mathrm{m}$ mesh sieve, and the fractions were subjected to further analysis.

Image analysis of the obtained F7 fractions (Figure 8 and 9) provided more detailed data on the particles size and shape. Figure 8 demonstrates that the majority of F7f 
particles was smaller than $1000 \mu \mathrm{m}$, although about 30\% particles lay in the range of $1000-1500 \mu \mathrm{m}$, indicating some particle aggregation after sieving. Dominant part of F7c particles sized between 1000 and $2000 \mu \mathrm{m}$. Figures 8 and 9 shows that F7c fraction had rather irregular shape, as reflected by the calculated circularity factor $(0.53)$, while F7f particles were more spherical in shape (circularity factor of 0.72 ). In addition, there was no notable difference in colour between $\mathrm{F} 7 c$ and $\mathrm{F} 7 f$ particles, indicating uniform coating of both fractions (Figure 7b).

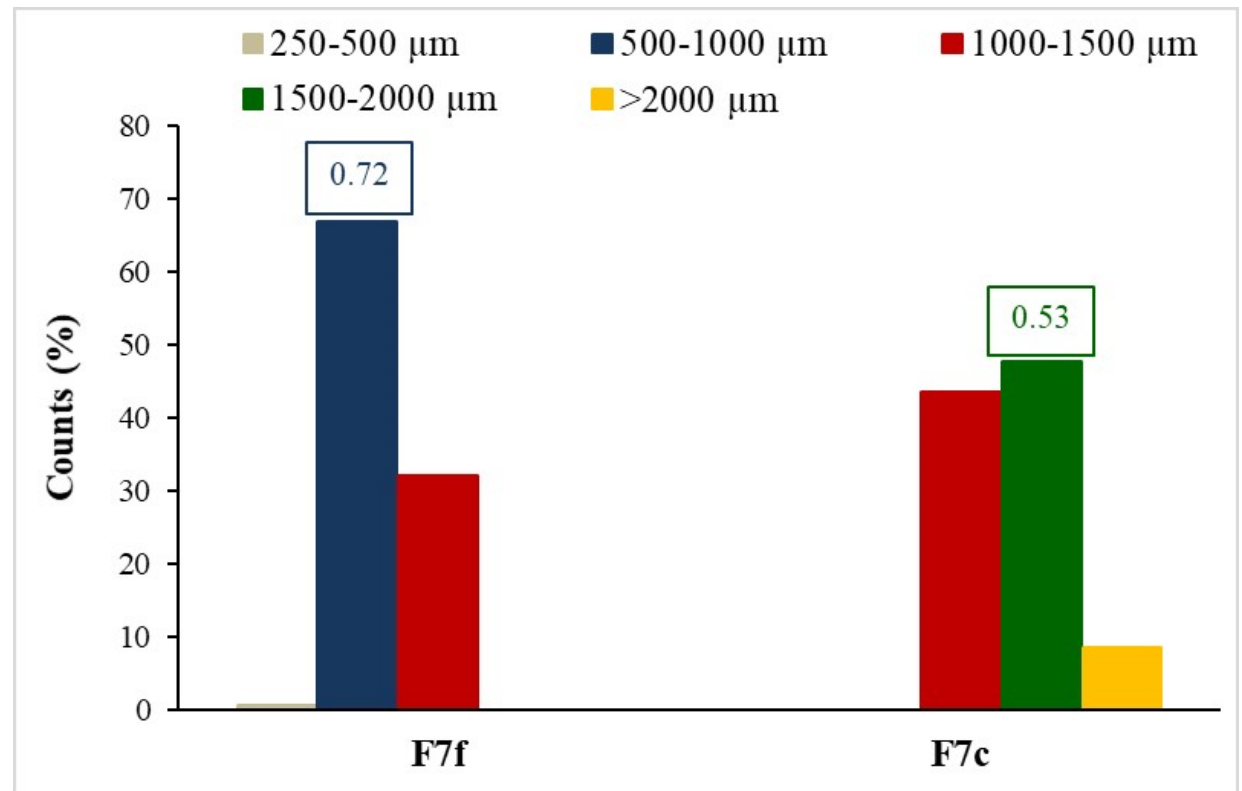

Figure 8. Particle size distribution and circularity factor (framed values) for sample F7: F7 $f$ (fine fraction), F7c (coarse fraction), determined by image analysis

Slika 8. Raspodela veličine i cirkularnost (uokvireni brojevi) čestica uzorka F7: F7f (sitne frakcije), F7c (krupne frakcije), određeni na osnovu analize slike

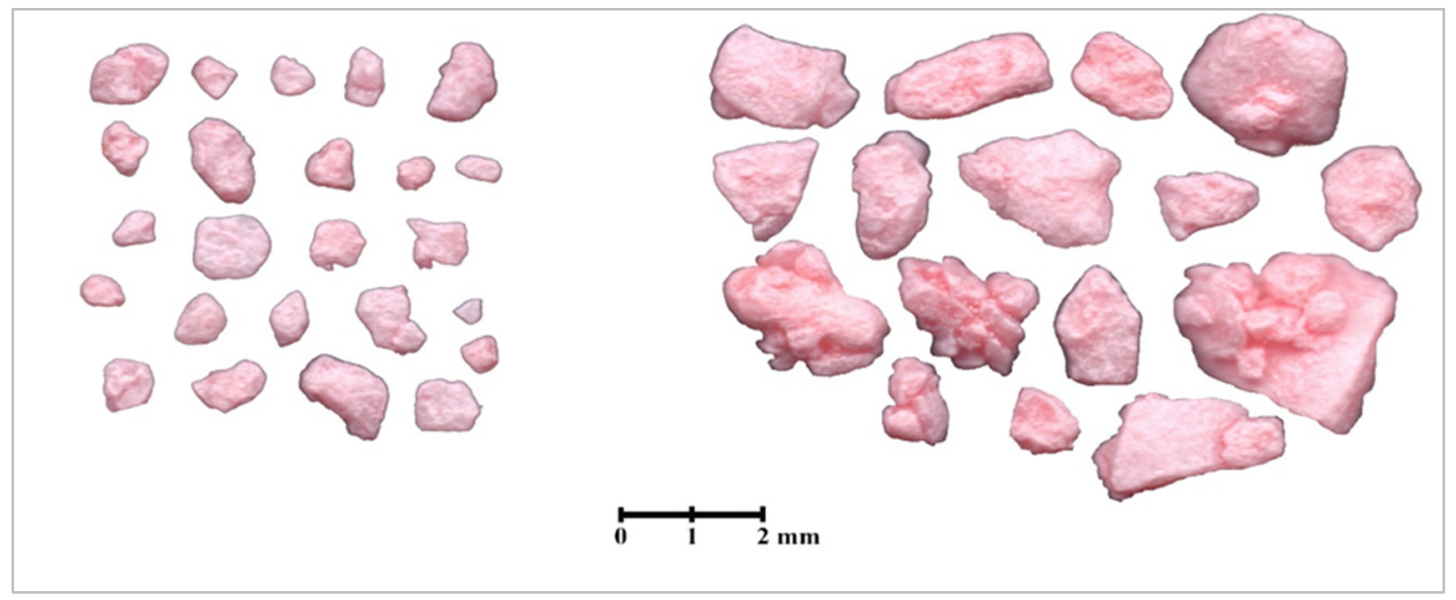

Figure 9. Scanned images of F7 sample: fine fraction (left) and coarse fraction (right) Slika 9. Skenirane slike uzorka F7: sitna frakcija (levo) i krupna frakcija (desno) 
The flowability of the two F7 fractions is presented in Figure 10, along with the data for the uncoated caffeine. The obtained results indicate that HMC improved caffeine flowability, and that fine coated fraction (F7f) possess better flow properties than the coarse fraction (F7c). In other words, increase in particle size led to decrease in sample flowability. This observation is in agreement with the results obtained for HMC sodium chloride samples. But, in contrast to sodium chloride samples, where coating decreased substrate flowability, both coated caffeine fractions showed better flowability that the uncoated caffeine (Figure 10). This finding can be explained by the fact that raw sodium chloride has good flowability, but raw caffeine is a poorly flowable drug (27), so it can be expected that the lipid coat will provide better lubrication of the material and enhance its flowability. Increased flowability of the coated caffeine was also reported in the study of Drašković et al. (25).

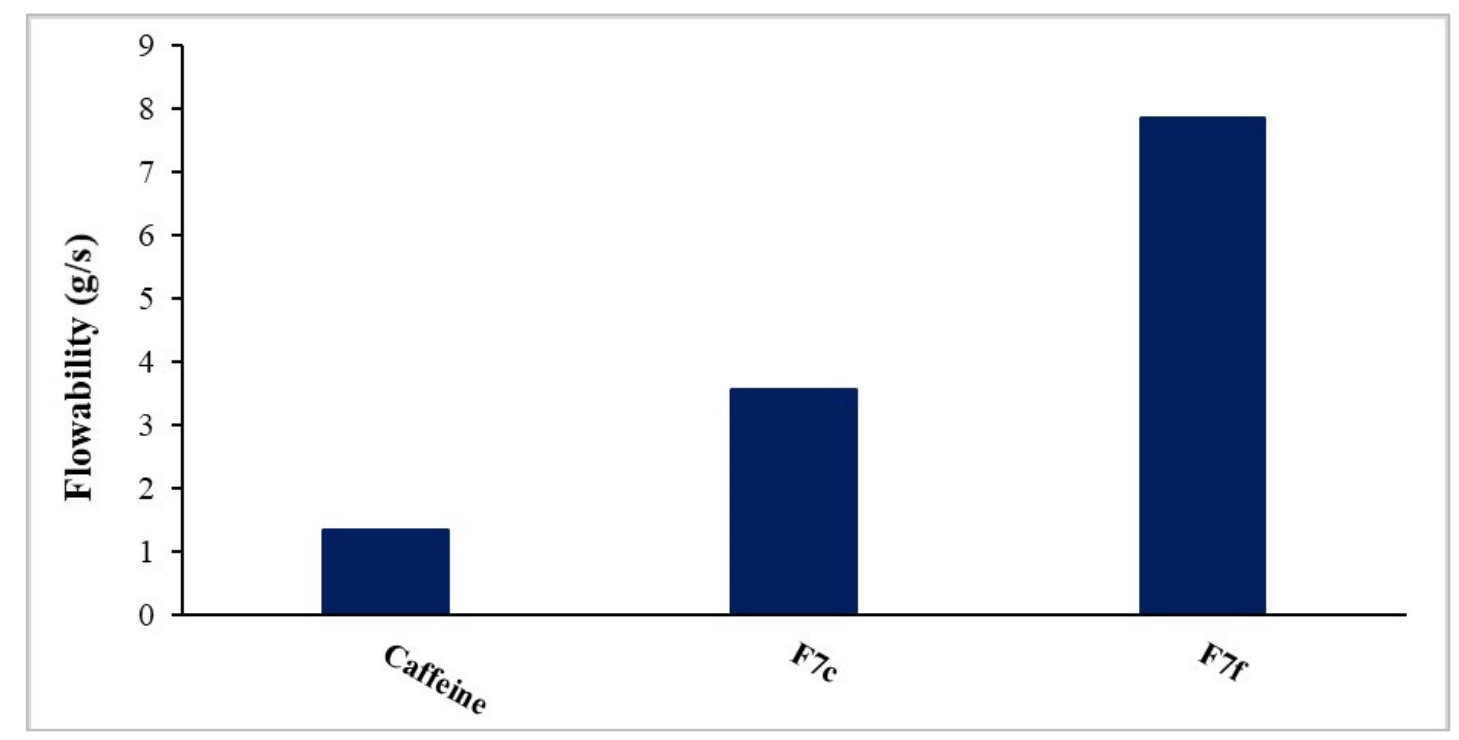

Figure 10. Flowability of uncoated caffeine and sample F7: F7f (fine fraction), F7c (coarse fraction), determined by the direct method

Slika 10. Protočnost neobloženih čestica kofeina i uzorka F7: F7f (sitne frakcije), F7c (krupne frakcije), određena direktnom metodom

Caffeine content in the coated material was $91.85 \%$ (F7c) and $81.34 \%$ (F7f), and these values were used to calculate percentage of caffeine dissolved from the tested samples. The obtained caffeine release profiles are depicted in Figure 11. The obtained results revealed somewhat slower caffeine release from the coarse fraction in comparison to the fine one (Figure 11). This is also reflected in the calculated $f_{2}$ value (43.40). In addition, less than 5\% caffeine released in $2.5 \mathrm{~min}$ from both $\mathrm{F} 7$ fractions indicated no burst drug release (e.g., during residence time in the oral cavity in the case of oral formulations). This implies that the suggested HMC method is suitable for caffeine taste masking. 


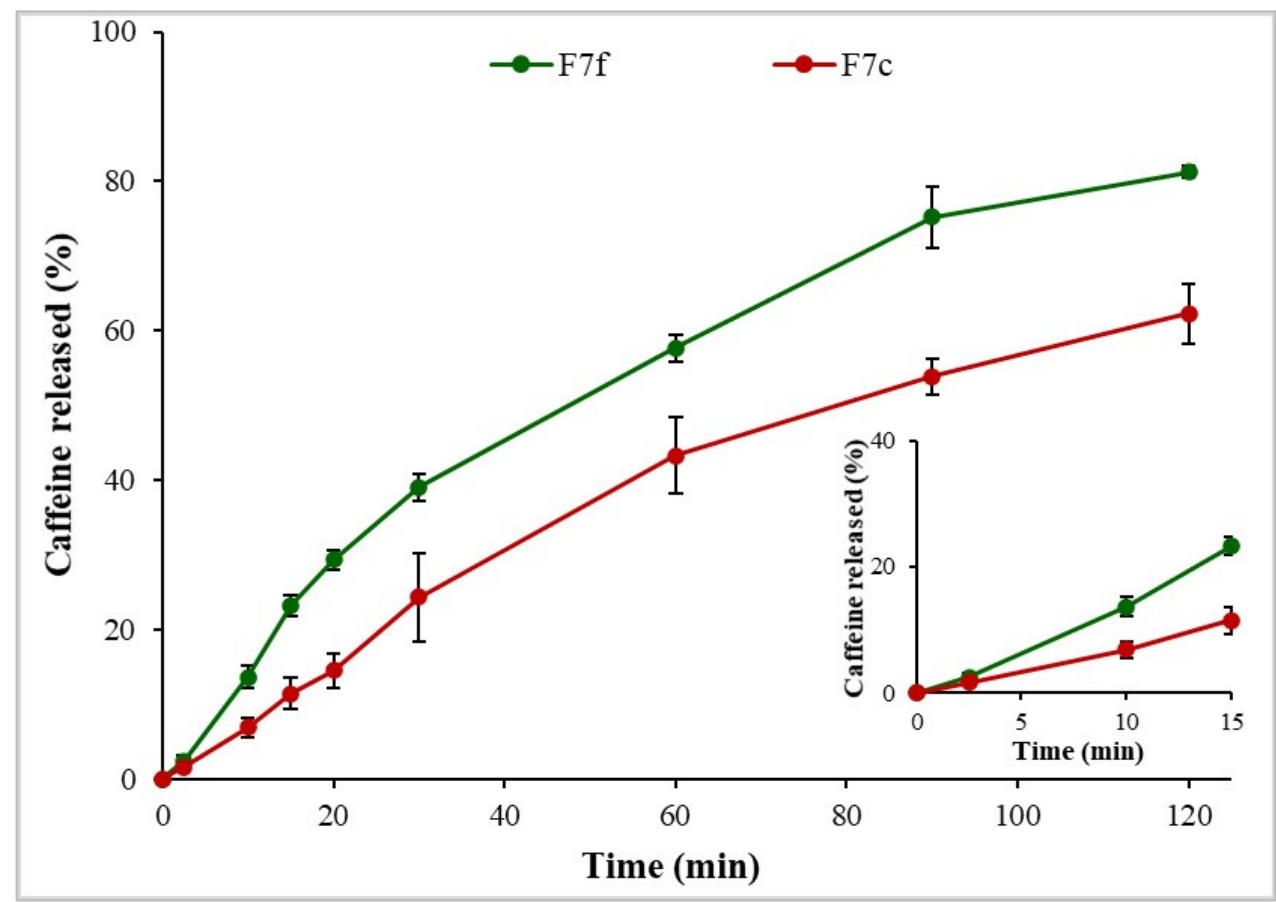

Figure 11. Caffeine dissolution profiles from sample F7: F7 $f$ (fine fraction) and F7c (coarse fraction). The inset shows the magnified initial phase (up to $15 \mathrm{~min}$ ) of the dissolution profiles

Slika 11. Profili brzine rastvaranja kofeina iz uzorka F7: F7f (sitne frakcije) i F7c (krupne frakcije). Umetnuta slika predstavlja uveličanu inicijalnu fazu (do 15 min) u profilima brzine rastvaranja kofeina

The obtained results with sodium chloride and caffeine as model substrates indicated that HMC efficacy, as well as functional characteristics of the coated samples, are affected by the initial substrate properties, but also by the applied HMC method and coating composition. Therefore, an adequate HMC method should be carefully evaluated for each substrate, depending on its properties and the desired coated sample characteristics.

According to the presented results, both pan-coating and mortar-coating can be useful for HMC of highly soluble drugs with unpleasant taste. However, mortar-coating can be considered as a more simple, practical and cost-effective method to be used in compounding pharmacies. This method provided high yield and efficient coating, as reflected in the sustained release rate of both substrates (sodium chloride and caffeine) from the coated samples, suggesting that it can be potentially used as a method to improve the palatability of the compounded oral dosage forms. 


\section{Acknowledgement}

This work was supported by the Ministry of Education, Science and Technological Development, Republic of Serbia (grant number 451-03-68/2020-14/200161).

\section{References}

1. Bose S, Bogner RH. Solventless pharmaceutical coating processes. Pharm Dev Techn. 2007;12:11531.

2. Kim KH, Jun M, Lee MK. Bioavailability of the common cold medicines in jellies for oral administration. Pharmaceutics. 2020;12(11):1073.

3. Sohi H, Sultana Y, Khar RK. Taste masking technologies in oral pharmaceuticals: recent developments and approaches. Drug Dev Ind Pharm. 2004;30(5):429-48.

4. Douroumis D. Practical approaches of taste masking technologies in oral solid forms. Expert Opin Drug Deliv. 2007;4:417-26.

5. Basu A, De A, Dey S. Techniques of tablet coating: concepts and advancements. A comprehensive review. RRJPPS. 2013;2(4):1-6.

6. Foroughi-Dahr M, Mostoufi N, Sotudeh-Gharebagh R, Chaouki J. Particle Coating in Fluidized Beds, Reference Module in Chemistry, Molecular Sciences and Chemical Engineering, Elsevier; 2017; p. 6-8.

7. Thies C, Dos Santos IR, Richard J, VandeVelde V, Rolland H, Benoit JP. A supercritical fluid-based coating technology 1: Process considerations. Journal Microencapsul. 2003;20(1):87-96.

8. Becker K, Salar-Behzadi S, Zimmer A. Solvent-free melting techniques for the preparation of lipidbased solid oral formulations. Pharm Res. 2015;32:1519-45.

9. Sudke SG, Sakarakar DM. Lipids - An instrumental excipient in pharmaceutical hot-melt coating. Int J Pharm Tech Res. 2013;5(2):607-21.

10. Milanović A, Aleksić I, Ibrić S, Parojčić J, Cvijić S. Hot-melt coating with Precirol ATO 5 in a fluidized-bed apparatus: Application of experimental design in the optimization of process parameters. J Drug Deliv Sci Technol. 2018;46:274-84.

11. Disch T, Haala J, Koeberle M. Hot-melt coated immediate-release taste-masked paracetamol and caffeine orally-disintegrating granules. Pullach: Hermes Pharma. 2016.

12. Patil A, Chafle S, Khobragade D, Umathe S, Avari J. Evaluation of hot melt coating as taste masking tool. Int Res J Pharm. 2011;2(8):169-72.

13. Becker K, Haack D, Salar-Behzadi S, Zimmer A. Oral pharmaceutical composition comprising tastemasked N-acetylcystein. United States patent US 9,636,307. 2017.

14. Pouton CW. Lipid formulations for oral administration of drugs: non-emulsifying, self-emulsifying and ‘self-microemulsifying'drug delivery systems. Eur J Pharm Sci. 2000;11:S93-8.

15. Jannin V, Cuppok Y. Hot-melt coating with lipid excipients. Int J Pharm. 2013;457:480-7. 
16. Lopes DG, Salar-Behzadi S, Zimmer A. Designing optimal formulations for hot-melt coating. Int J Pharm. 2017;533(2):357-63.

17. Becker K, Saurugger EM, Kienberger D, Lopes D, Haack D, Köberle M, Stehr M, Lochmann D, Zimmer A, Salar-Behzadi S. Advanced stable lipid-based formulations for a patient-centric product design. Int J Pharm. 2016;497(1-2):136-49.

18. Kraahs P, Bold S, Fahsel L. Melt-coated pharmaceutical composition with fast release. United States patent US 8,481,060. 2013.

19. Freund M, Csikos R, Keszthelyi S, Mózes GY. Applications of paraffin waxes and liquid paraffins. In: Mózes GY, editor. Paraffin products: properties, technologies, applications. Elsevier Scientific; 1982; p. 240-329.

20. Szewczyk E, Karlowicz-Bodalska K, Han S, Musial W. Influence of liquid paraffin, white soft paraffin and initial hydration on viscosity of corticosteroid cream. Trop J Pharm Res. 2014;13(8):1233-8.

21. European Pharmacopoeia, 10th ed, Strasbourg: Council of Europe, 2019.

22. Kolafa J. Solubility of $\mathrm{NaCl}$ in water and its melting point by molecular dynamics in the slab geometry and a new BK3-compatible force field. J Chem Phys. 2016;145(20):204509.

23. Schneider CA, Rasband WS, Eliceiri KW. NIH Image to ImageJ: 25 years of image analysis. Nat Methods. 2012;9(7):671-75.

24. The Merck Index - An Encyclopedia of Chemicals, Drugs, and Biologicals. 15th ed. O'Neil MJ, editor. Cambridge, UK: Royal Society of Chemistry; 2013; p. 1596.

25. Drašković M, Medarević D, Aleksić I, Parojčić J. In vitro and in vivo investigation of taste-masking effectiveness of Eudragit E PO as drug particle coating agent in orally disintegrating tablets. Drug Dev Ind Pharm. 2017;43(5):723-31.

26. Moore JW, Flanner HH. Mathematical comparison of curves with an emphasis on in vitro release profiles. Pharm Tech. 1996;20(6):64-74.

27. Szumilo M, Belniak P, Swiader K, Holody E, Poleszak E. Assessment of physical properties of granules with paracetamol and caffeine. Saudi Pharm J. 2017;25(6):900-5. 


\title{
Procena metoda za oblaganje višečestičnih supstrata topljenjem: oblaganje u pateni $v s$. oblaganje u bubnju
}

\author{
Jelisaveta Ignjatović ${ }^{1}$, Jelena Đuriš ${ }^{1}$, Mihal Đuriš², Teodora Bočarski ${ }^{1}$, \\ Vanja Vasilijević ${ }^{1}$, Ivana Aleksić ${ }^{1}$, Sandra Cvijić ${ }^{1 *}$ \\ ${ }^{1}$ Univerzitet u Beogradu - Fakultet za farmaciju, Katedra za farmaceutsku tehnologiju i \\ kozmetologiju, Vojvode Stepe 450, 11221 Beograd, Srbija \\ ${ }^{2}$ Univerzitet u Beogradu - Institut za hemiju, tehnologiju i metalurgiju-Nacionalni \\ institut Republike Srbije, Odeljenje za katalizu i hemijsko inženjerstvo, Njegoševa 12, \\ 11000 Beograd, Srbija
}

*Autor za korespondenciju: Sandra Cvijić, E-mail: gsandra@pharmacy.bg.ac.rs

\section{Kratak sadržaj}

Oblaganje topljenjem je alternativna metoda oblaganja, bez upotrebe rastvarača i uglavnom se koristi za modifikaciju brzine rastvaranja i/ili maskiranje neprijatnog ukusa supstrata. Cilj ovog rada je da se procene dve metode za oblaganje topljenjem (oblaganje $u$ bubnju i oblaganje $u$ pateni), ispitivanjem funkcionalnih karakteristika obloženog materijala. Izabrana su dva visoko rastvorljiva supstrata: natrijum-hlorid (model supstanca) i kofein (lekovita supstanca gorkog ukusa), a za oblaganje je korišćen glicerildistearat bez/sa dodatkom tečnog parafina.

Eksperimenti sa natrijum-hloridom su pokazali da su oblaganjem u bubnju dobijene čestice pravilnijeg oblika, dok su oblaganjem u pateni dobijeni uzorci sa ujednačenijom oblogom. Protočnost obloženog materijala je zavisila od veličine čestica. Usporeno rastvaranje natrijumhlorida postignuto je kod svih uzoraka obloženih u pateni i kod nekih uzoraka obloženih u bubnju. Analiza rezultata je izdvojila oblaganje u pateni kao pogodniju metodu za oblaganje kofeina. Dobijeni prinos obloženih čestica kofeina je bio visok (99\%), obloženi materijal je imao zadovoljavajuće mehaničke osobine i postignuta je usporena brzina rastvaranja kofeina. Sumarno, dobijeni rezultati su pokazali da se i oblaganje u bubnju i u pateni mogu koristiti za usporavanje rastvaranja lekovitih supstanci neprijatnog ukusa, no oblaganje u pateni predstavlja jednostavniju i praktičniju metodu koja se potencijalno može koristiti i u izradi magistralnih lekova.

Ključne reči: oblaganje topljenjem, oblaganje u bubnju, oblaganje u pateni, višečestični sistemi, funkcionalne karakteristike 